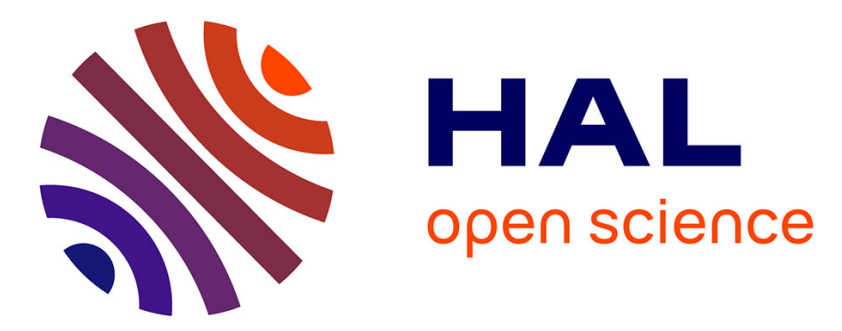

\title{
Challenges for Knowledge Management in the Context of IT Global Sourcing Models Implementation
}

Kazimierz Perechuda, Malgorzata Sobińska

\section{To cite this version:}

Kazimierz Perechuda, Malgorzata Sobińska. Challenges for Knowledge Management in the Context of IT Global Sourcing Models Implementation. 2nd IFIP International Workshop on Artificial Intelligence for Knowledge Management (AI4KM), Sep 2014, Warsaw, Poland. pp.58-74, 10.1007/978-3319-28868-0_4. hal-01369801

\section{HAL Id: hal-01369801 \\ https://inria.hal.science/hal-01369801}

Submitted on 21 Sep 2016

HAL is a multi-disciplinary open access archive for the deposit and dissemination of scientific research documents, whether they are published or not. The documents may come from teaching and research institutions in France or abroad, or from public or private research centers.
L'archive ouverte pluridisciplinaire HAL, est destinée au dépôt et à la diffusion de documents scientifiques de niveau recherche, publiés ou non, émanant des établissements d'enseignement et de recherche français ou étrangers, des laboratoires publics ou privés. 


\title{
Challenges for knowledge management in the context of IT global sourcing models implementation
}

\author{
Kazimierz Perechuda ${ }^{1}$ and Małgorzata Sobińska ${ }^{2}$ \\ ${ }^{1}$ Wrocław University of Economics \\ kazimierz.perechuda@ue.wroc.pl \\ ${ }^{2}$ Wrocław University of Economics \\ malgorzata.sobinskadue.wroc.pl
}

\begin{abstract}
The article gives a literature overview of the current challenges connected with the implementation of the newest IT sourcing models. In the dynamic environment, organizations are required to build their competitive advantage not only on their own resources, but also on resources commissioned from external providers, accessed through various forms of sourcing, including the sourcing of IT services. This paper presents chosen aspects of knowledge management and knowledge and information security, in the context of IT sourcing models implementation. IT sourcing solutions are presented, as employed by modern companies, together with potential benefits offered. The main focus is put on the determination of the most important risks involved in knowledge sharing in IT sourcing relations, as well as minimization and reduction of such risks, with particular attention to the newest trend in IT sourcing - cloud computing services on offer.
\end{abstract}

Keywords: management, knowledge management, IT sourcing models, cloud computing, information security

\section{Introduction}

Businesses are on the lookout for newer and more innovative ways to enhance competitiveness and get ahead of the growth curve. A new generation of advanced technologies - social, mobility, analytics and cloud have taken the center-stage, promising to transform enterprises and help 
them do business better. Enterprises that embrace these technologies would be able to seamlessly redesign their business models, strategy, operations and processes to meet the new customer demands.

A review of the wider outsourcing literature (e.g.[1],[10],[17,[18]) provides a basis to the claim, that as outsourcing spend increases, the alignment of business and sourcing strategy becomes a key issue and needs from CEO and business executive involvement in outsourcing objectives, relationships and implementation.The authors suggest a range of key issues that could be usefully researched in the context of IT sourcing implementation and functioning of IT sourcing relation.

In this article the attention will be paid to the knowledge and information management in IT sourcing relation. The main objective is to analyze the risks and opportunities of knowledge and information sharing in IT sourcing cooperation.

In authors opinion, the aspects of knowledge management in outsourcing relationship is relatively underrepresented in professional literature and too often underappreciated in practice. It can lead to a variety of negative effects, such as organizational problems, limited communication with service suppliers, low quality of services rendered, mounting costs as well as growing barriers to exit from the outsourcing deal.

The IT departments of modern organizations are still more and more reliant on the services of external providers and suppliers of hardware, software, telecommunication, cloud computing resources, etc. By end of 2013 global outsourcing contract value for business and IT services was about \$US648 billion (BPO \$304b., ITO \$344b.), and by the end of 2014 exceeded \$US700 billion. On some estimates the market will see $4.8 \%$ compound annual growth through to end of 2018 as more is outsourced, and new service lines and delivery locations are added. Within this, offshore outsourcing exceeded $\$ 100$ billion in revenues in 2013 and we estimate it to grow at 8-12\% per year from 2013 to 2018. At the same time, despite the increased popularity of IT sourcing, the satisfaction from this type of business model of IT management remains at a relatively low level [15].

One of the objectives of the pilot study of Willcocks and Sobinska was to provide answer to the following question: "Which IT sourcing models are, in the respondents' opinion, burdened with excessive risk?" [15]

When asked about the evaluation of risk involved in various sourcing models, the respondent companies pointed out the elevated risks in offshoring (54\%) and cloud computing (25\%). Those two IT sourcing models are decidedly less popular among Polish companies as at 2014, but the interest in cloud computing solutions is expected to grow in the near future and, with maturity, cloud sourcing emerges as quite attractive for respondent Polish companies. 
The reluctance to share information and knowledge, as well as the lack of trust (30\% of the responses) were high on the list of risks materializing reported by companies (see Fig. 1).

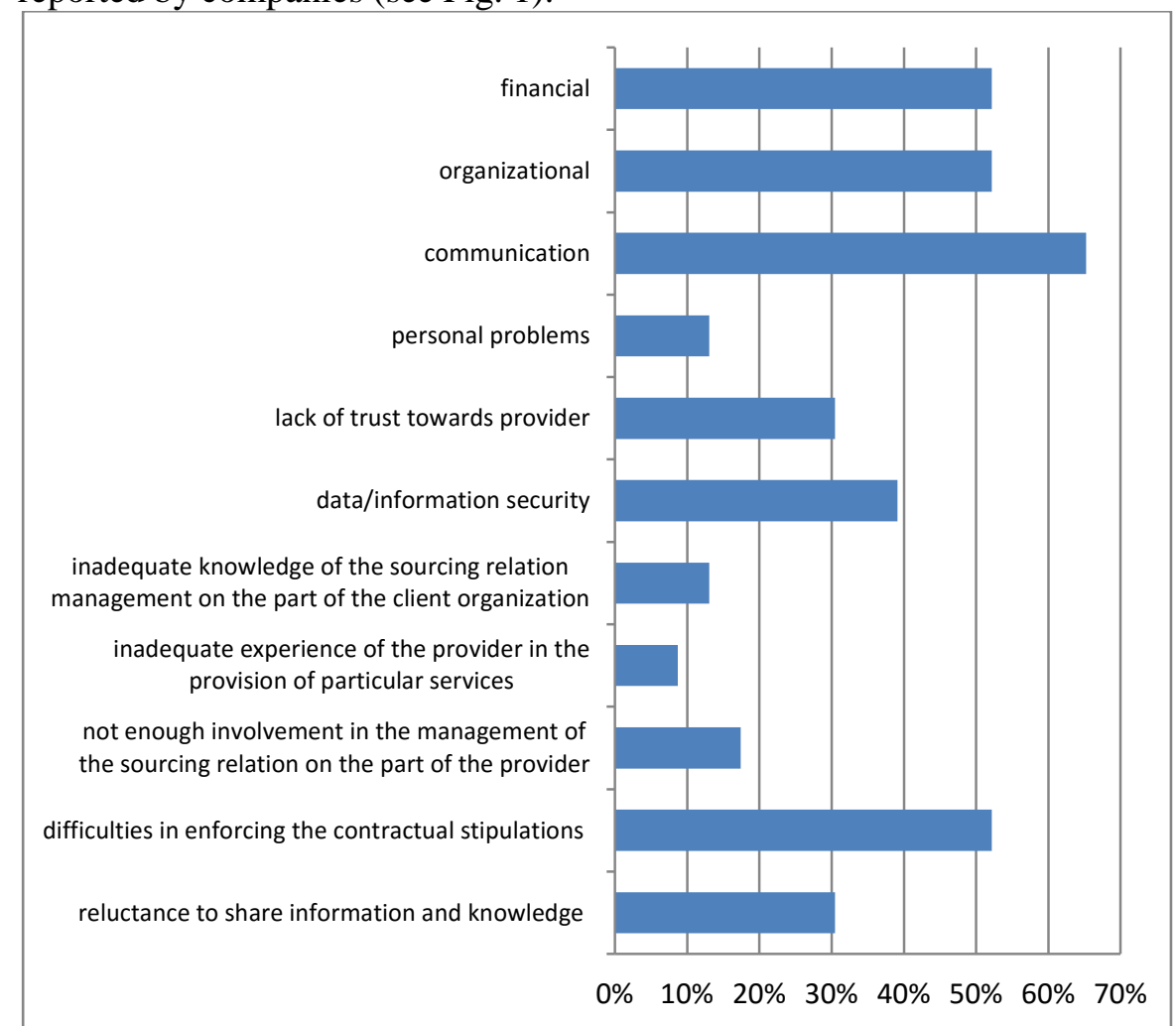

Figure 1. The most important risk factors materializing in the IT sourcing process (Source: [15]).

The business models employed by modern enterprises are increasingly more involved in problems related to the security and protection of information, data, and knowledge, particularly of the classified and undisclosed type.

In a sense, these business models can be viewed as based on knowledge and security. The classified knowledge (technical, technological, design, logistic, etc.) is one of the core competences of large network corporations, such as Renault, Mazda, Opel, Toyota, Deutsche Bank, and others.

The network structure of large corporations, while designed to provide competitive advantage in two areas, namely:

- outsourcing of ancillary functions, support functions, and even primary functions (as in the case of Opel assembly factory in Gliwice), 
- centralized investment in $\mathrm{R}+\mathrm{D}$ and new technologies (patents, inventions, improvements, copyrights),

may also increase the risk of uncontrolled 'leakage' of key undisclosed knowledge (technical, design, technological, financial, trade, etc.) to market competitors. This is a direct result of the increased access to core corporate knowledge offered to cooperating entities.

The most important aspect of this process is the natural outflow of hot knowledge, resulting from transmigration of knowledge agents (managers and long-term employees with unique competences and experience), in both the networked and non-networked systems.

\section{Methodology}

This paper combines literature review with the authors comments. It presents a wider look on the knowledge management and security in IT sourcing relationship, that was partly discussed in the paper "Information security in IT global sourcing models"'[14].

\section{New global sourcing models of business}

In the modern, 'flat' model of economy, networked enterprises build their competitive advantage through careful selection of sourcing agents. One of the most important criteria for such selection is the perceived level of security with respect to uncontrolled and undesired outflow of data, information, and knowledge from organizations to other entities outside their network structure.

Sadly, this particular criterion is rarely perceived as mission-critical. Companies tend to prioritize the aspect of compatibility between core competences of the potential sourcing partner with key competences and resources of the mother company. The increased asymmetry of key competences between sourcing partners may result in the following trends (Fig. 2):

- departure (short-term contracts, rapid capturing of the partner's know-how),

- unification (strengthening the cooperation, balancing the symmetry of undisclosed knowledge, participation in future projects). 


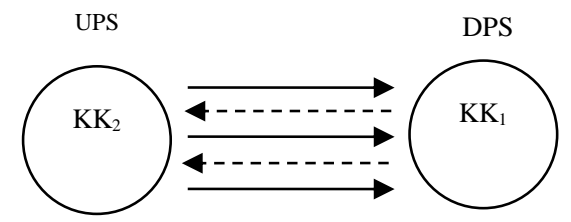

B. The departing trend

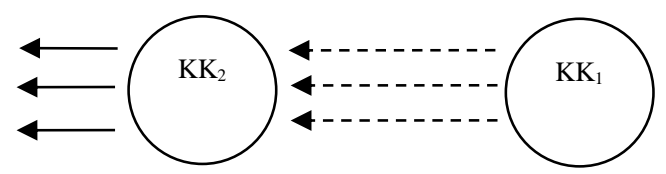

where:

DPS - the dominant sourcing partner UPS - the dependent sourcing partner $\mathrm{KK}_{1,2}$ - key competences

Figure 2. Trends in sourcing cooperation (source: own research).

New needs of enterprises result in the emergence of new types of global sourcing models, where sourcing can be defined "as the act through which work is contracted or delegated to an external or internal entity that could be physically located anywhere" [1, p. 2]. Sourcing can also be defined as a comprehensive organizational strategy for distribution of business processes and other functional areas of the enterprise among cooperating partners. For the purpose of this study, sourcing is defined as a notion of superior level to the notions of outsourcing and insourcing [2, p.17]. The main differences between sourcing models involve determination of the following factors:

- is the sourced function delegated to a dependent entity or an independent external supplier (or both), and

- is the sourced function performed on-site or off-site, is it performed onshore, nearshore (in a neighboring country) or offshore (in a remote location) [1, p. 25].

A business model of IT sourcing may comprise the following types/models of sourcing cooperation/relation (own research, based on: [7, pp. 6-16]; [1, pp. 26-42]; [5, p. 1300]; [6]]: facility management, selective outsourcing, tactical outsourcing, transformational outsourcing, transitional outsourcing, Business Process Outsourcing, joint ventures, benefitbased relationships, insourcing (staff augmentation), offshore outsourcing (foreign supplier), nearshore outsourcing (foreign supplier), onshore outsourcing (domestic supplier, "rural sourcing"), cosourcing, shared services, 
captive models and models based on Internet: cloud computing, software as a service, crowdsourcing and microsourcing. Figure 3 presents a graphic representation of a general model of IT sourcing.

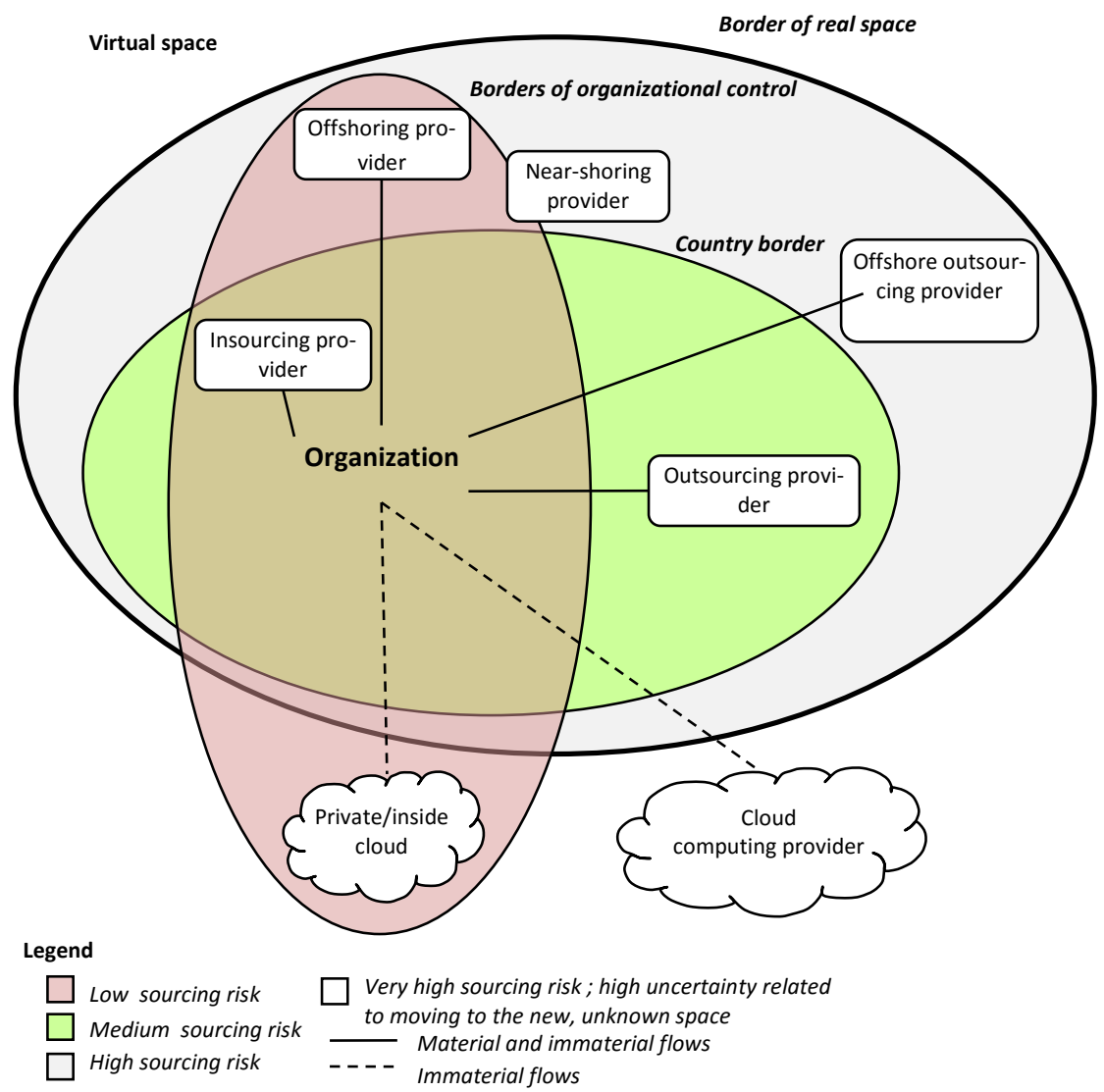

Figure 3. A general model of IT sourcing (source: [6]).

A large number of modern organizations operate simultaneously in two business areas: the real and the virtual. The greater the availability of resources, the greater the potential impact. The more we expand the range of the network (new locations where functions/processes/services of an organization are implemented; greater number of sourcing providers; new areas of service delivery such as cloud computing), the greater the potential opportunities, but also the greater is the risk involved.

A decision to implement a particular sourcing model may be influenced by the following factors (own research, based [7, p.4]:

- the global skills shortage,

- a more mobile workforce, 
- the mounting cost of in-house developed software,

- the need to move fast, rapidly adopting new technologies and speeding up system development,

- the explosion of Internet technologies and services requiring a wide range of new skills and investments.

For the purpose of this study, the authors focus on the presentation and analysis of one of the most popular Web-based sourcing models - the cloud computing - without going into detailed analysis of other IT sourcing models in use.

Cloud computing allows users to access technology-enabled services on the Web, without having to know or understand the technology infrastructure that supports them. Nor do they have much control over it. It is an innovative way to boost capacity and add capabilities in computing without spending money on new infrastructure, training new personnel or licensing software.

There are four basic types of clouds: private clouds (operated solely for the use of a single organization), community clouds (operated for a specific group that shares infrastructure), public clouds (which use cloud infrastructure available over a public network) and hybrid clouds (which combine the infrastructure of two or more clouds - public, community, and private).

The increased risk of cloud computing projects has to do with opening up the organization to a whole new space, which is not yet completely examined and "protected". The range of potential risk scenarios is impossible to predict at this moment, since they have yet to be observed in organizational practice. At the same time, the output and the use of the "new space-clouds" can increase the potential added value of using this type of sourcing, compared to more classical forms, such as the generic outsourcing and offshoring models.

New forms of contracting, and - consequently - new resource acquisition methods are required to help modern organizations survive in this age of innovation and strong competition. However, it should be noted that those new solutions, as any new ideas, come with new risks and new demands for management. Some of those risks with the principles and methods conducive to their reduction will be discussed in the following sections of the paper.

\section{Knowledge management in IT sourcing relationship}

Using the services of external provider can become a driver of cultural change processes of an organization and encourage organizational renewal. However, a prerequisite for such a change is the full commitment of ma- 
nagement staff. An outsourcing provider can play a dual role in the process of change - on the one hand he can perform professional services innovation and integration, on the other hand he has the tools to carry out organizational and cultural change throughout the organization [2, p. 36].

One can characterize the potential and risks of IT outsourcing in the context of knowledge management as follows:

- Outsourcing (including offshore outsourcing) is conducive to broaden the organizational and technological knowledge of an organization. Specialized IT service providers provide an access to the expertise and skills of experts, which the organization does not have, and that is hard to find in the local market. Planning outsourcing model implementation forces deepening and formalization of knowledge about the organization - the evaluation of its key resources, competencies, implemented processes and needs, as well as the environment - the market opportunities in the provision of IT services. Thanks to the preparation and the implementation of the outsourcing contract organization gets a lot of experience on how to manage outsourcing relationship and the problems that may arise in the course of cooperation with external service providers.

- Outsourcing is conducive to establishing informal relations between customer and service providers employees, which facilitates the exchange of information (including know-how), and helps to followup activities of the experts.

- Offshore outsourcing of IT services, although associated with a higher risk and communication difficulties is an opportunity not only to gain access to expertise, but also to observe the best practices of global IT services providers on the standardization and formalization of work, thereby ensuring a better control of the implemented services.

- Outsourcing and offshore outsourcing provides new business contacts and experience in the management of this type of projects.

- The risk of outsourcing and offshore outsourcing (also in the context of knowledge management) is much smaller, if it does not apply to areas and functions that are crucial for the functioning of the organization.

- The experience of Indian offshoring companies customers give rise to the claim that outsourcing services to the companies in the same industry is very risky. Knowledge, which is sent to the provider can greatly weaken the position of the organization and to strengthen the position of the supplier.

Positive and negative experiences with the use of outsourcing in areas such as e.g. information technology, where appropriate transfer of knowledge between the contract parties (especially in the case of total out- 
sourcing) often determines the success or failure of cooperation, suggest that the model of knowledge management in IT sourcing could not only fill the research gap, but also be used in practice.

The effective management of IT outsourcing cooperation requires qualified personnel with suitable skills and knowledge.

The issue of knowledge management in relationships with external suppliers was discussed by M. Sobińska in her previous publication. The author defined knowledge management in outsourcing projects as "an identification and coordination of processes that influence: knowledge localization, knowledge development, knowledge exchange, knowledge utilization and preservation of knowledge related to carrying out the outsourcing process, based on the use of properly selected methods and instruments and intended to facilitate completion of the outsourcing goals as well as extending of organizational knowledge" [16, p. 205].

Figure 4 presents a model of knowledge management processes in IT outsourcing.

From the perspective of knowledge management outsourcing can be defined as (based on [19, p. 394 ]):

- a way of acquiring expertise and skills that the organization does not possess;

- the form of stabilization of the knowledge related to the functioning of selected areas of an organization;

- a guarantee to keep up with technological development (in this case, an outsourcing contract should include appropriate conditions obligating the provider to continuous development and improvement of the provided services);

- a replacement of the internal know-how with the same kind of knowledge from the outside. 


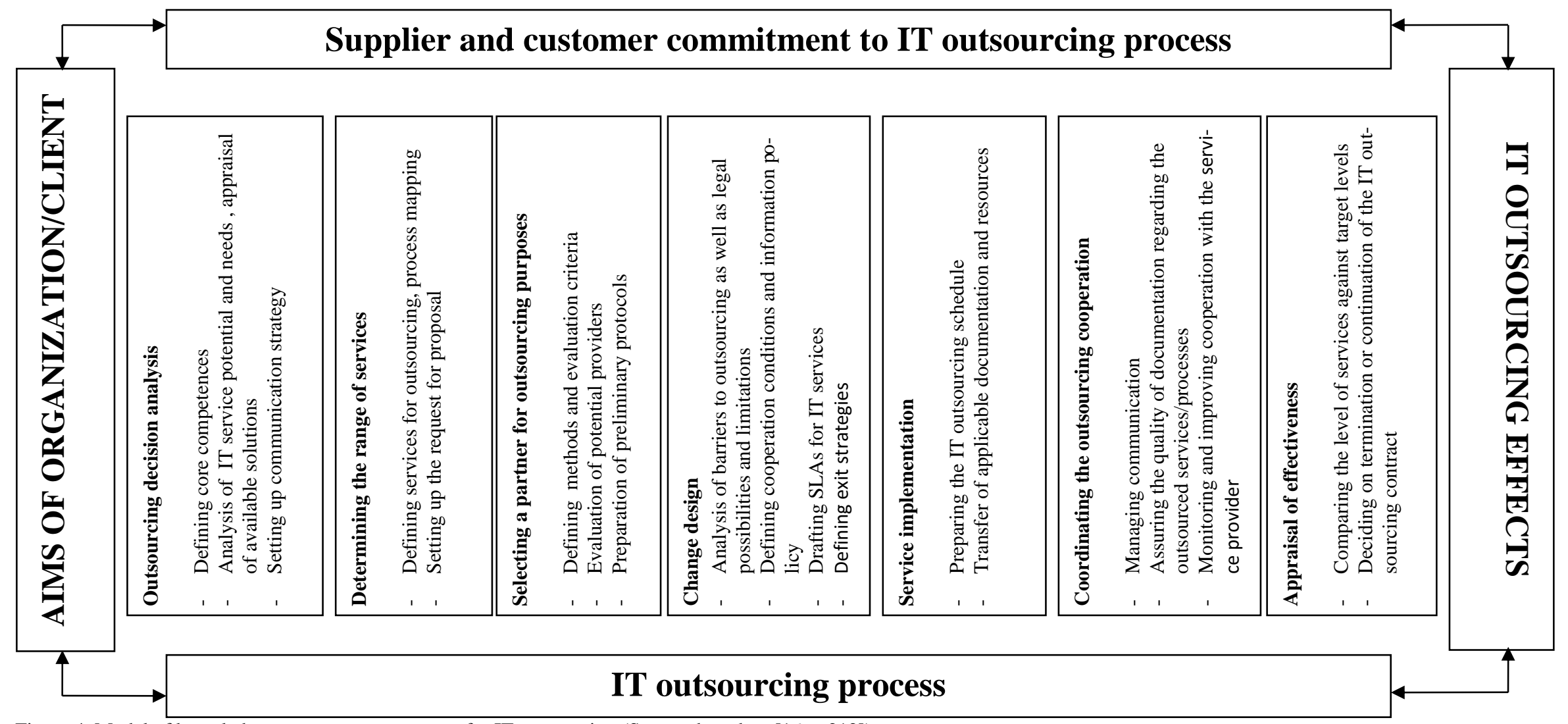

Figure 4. Model of knowledge management processes for IT outsourcing (Source: based on [16, p.212]). 
Knowledge management in IT outsourcing relationship should enable creation and utilization of intellectual capital, that, in Willcocks opinion, should be generated through the interplay between such essential elements as [1, p.111-112]:

- structural capital (that refers to the codified bodies of semipermanent knowledge that can be transferred and the tools that augment the body of knowledge by bringing relevant data or expertise to people),

- human capital (which represents the capabilities of individuals to provide solutions to customers),

- customers capital (that is linked to shared knowledge, or the value of an organization's relationships with the people with whom it does business)

- and social capital (for example: trust, loyalty and reciprocity within a community- the values created from social networks), which helps bring these elements together.

Outsourcing implementation frequently disrupts and reduces social capital by removing people, systems, and organizational knowledge from the client organization. It should be paid more attention to strengthening the social capital as it can have a considerable impact on effective knowledge transfer between outsourcing parties. Social capital allows outsourcing partners reduce for example cultural barriers, understand common goals and strengthen network stability and ties.

Modeling of knowledge management processes in outsourcing relationships can significantly contribute to:

- reducing the difficulties of communication with an external provider, improve the process of IT sourcing implementation, better protection of organizational knowledge,

- effective information and knowledge exchange in both customersupplier and supplier-customer relationship,

- the real development of organizational knowledge during the outsourcing contract (both organizational knowledge about project management and expertise (which is especially important if the organization after the contract termination wants to return to providing services internally),

- improvement of the outsourcing process for achieving the strategic objectives of the organization.

Still more and more outsourcing clients believe that part of an outsourcing transaction is access to innovative thinking. At the same time the teams mana- 
ging the relationship with the supplier focus on reducing costs and effectively block any proposal (from the providers) to amend and modify the outsourced services not passing them on to the end users and top management.

Therefore it is quite important for the client organization to give to the provider the right to make "valuable" proposals (which could have a significant positive impact on the functioning of the organization) directly to the Executive Director or/and top management. The provider should also be able to provide suggestions concerning the activities/operations that are out of the contract, if they were to foster innovation [2, pp. 165-166].

The need for innovation resulting from changing business conditions, economic slowdown and globalization and technologization of services delivery enforces a new look at sourcing relationships and the transition from outsourcing management to cooperation for innovation. This change is realistic but requiring from the engaged parties: high maturity, mutual trust, high competence, commitment and flexibility.

These actions resulting from the proper approach to knowledge management in relationships with the IT services providers would gradually move the organizations from basic services sourcing model towards innovative cooperation.

One of the modules of knowledge management in outsourcing relationships, especially in the area of IT should be the information and data security management, that will be discussed in the next chapter. It could be particularly important for the implementation of cloud solutions, especially in cooperation with foreign service providers.

\section{Information and knowledge security in the IT sourcing models}

Information security is one of the key factors to be taken into account in the context of sourcing decisions, particularly those which involve cooperation with external partners. Potential contractors may operate from remote locations, often in diverse cultural, political, social, legal, and other settings. The problem of information security is also reported as one of the main concerns for potential cloud computing users and clients.

According to K. Liderman, information security comprises all forms (also verbal) associated with the exchange, storage, and processing of information. It represents the risks involved in information resource loss, as well as misinformation resulting from poor quality of information provided. It must be no- 
ted that K. Liderman makes a clear distinction between information security and 'security of information'. The latter, a subset of information security, is defined as "justified trust (e.g. based on risk analysis and the adopted risk management procedures) that the organization will not face potential losses as a result of undesired (accidental or intentional) use of information stored, processed, and transmitted within the system, be it information disclosure, modification, removal, or rendering it unfit for processing purposes" [4, p. 22]. The problem of information security, despite increased publicity in professional literature and media, is still trivialized by managers of many companies. And, while the managerial personnel declare their knowledge of risks involved in this area (as reported in many studies, see: [11, p.19], in practice they tend to minimize their efforts with respect to information security. The main reasons for negligence are: the financial outlay, and the lack of competences. For instance, not many companies are able to perceive the risk associated with the fact that company information is no longer contained within the 'company perimeter'. Nowadays, information flows freely, and the risk of disclosure is far more pronounced. The lack of informed approach to the risk management process is a fast lane to disaster, since potential incidents may gravely affect the security or company development. Modern organizations face the serious challenge of implementing effective security strategies, with proper risk management as one of the main elements of the system [5].

In this context, outsourcing may be seen as a chance to improve information security (and the security of IT systems) by transferring the IT security responsibilities to an external provider with proper specialist knowledge and IT technologies. On the other hand, it may just as well add to the risk, by opening up sensitive company resources to external agents. Those resources may (unwillingly or intentionally) be used to detrimental effects.

Since cloud computing has become a hot topic in IT management, it may be useful to address some of the security issues involved in this form of cooperation. In terms of information security, the main difference between traditional IT structures and cloud solutions is the fact that cloud infrastructure is interspersed and shared among many users. In addition, certain features of cloud computing, such as the need for continuous optimization, improved access, balancing the computing load across the nodes, etc., bring additional complications to the risk management process.

At present, three main categories of cloud computing solutions can be distinguished, namely: SaaS - Software as a Service, PaaS - Platform as a Service, and IaaS - Infrastructure as a Service. Factors of potential risk to information security include the following [12, p. 230]:

- IT system's resistance to intrusive attacks from outside, 
- Resistance to internal attacks (with users able to access and capture information belonging to other users, by exploiting security holes and other vulnerabilities of the system),

- The security verification and encryption methods in use (whether the access codes and passwords are stored in secure, encrypted form, or stored and transmitted in open text).

Each of the above models of cloud computing (SaaS, PaaS, IaaS) employs a specific set of information security solutions [12, pp.232-233]:

- In the SaaS model, users rely on service provider in all matters concerning information security. The provider is responsible for restricting access to sensitive information, as well as supplying proper security measures to prevent intrusion or breakdown. The provider is also responsible for all matters concerning access verification and data encryption. However, the user is rarely able to examine the details of the security measures taken, to make sure that they are up to the desired standard of service.

- In the PaaS model, the service provider may choose to grant the software provider some control over the system security (for instance, the software provider may take on the responsibility of providing their own access verification and encryption systems), but any security issues beyond the application level, such as the security of host machines or network, come under the administration of the service provider. The provider may choose to pass on to the user selected details on the security measures in use.

- In the IaaS model, the software producer has a great deal of control over security mechanisms, since the cloud applications are run on virtual machines, independent and separated from virtual machines used by other users. However, applications in this model take longer to develop, and are decidedly more costly.

The majority of cloud computing service providers offer data backup solutions. This aspect is clearly important from the user's viewpoint, but it must be noted that data backup is not a $100 \%$ solution for all security concerns. The SaaS model, in particular, seems the most risky solution in the context of information security. In this model, both the software code and the data being processed are stored remotely (i.e. outside the subscriber's real machine). Consequently, the user has no access to computing operations, and is in no way able to modify it. SaaS offers the potential for server operator to modify the computing software or data processing procedures. Users must upload their data on the server for computing. The result is the spyware effect: the server operator receives user data freely and effortlessly, due to the character of the 
service rendered, and this gives him the unfair advantage (or even power) over the user. With the IaaS model, on the other hand, it is advisable to refrain from implementing needless functions on virtual machines, as well as making sure that all virtual machine images communicate over encrypted channels, so as to eliminate the risk of data capture on the network infrastructure level.

According to A. Mateos and J. Rosenberg, the security of the cloud computing environment is comparable to that of most internally managed systems, because:

- Most of the potential (and known) risk problems can be eliminated by employing the existing technologies, such as data encryption and virtual local area networks (VLAN), as well as standard tools, such as firewalls and packet filtering (encrypted data stored on cloud may in fact be safer than non-encrypted data used locally);

- Cloud computing solutions may be supplemented by additional controlling and auditing functionality, layered outside the environment of the host. Such a solution offers the user greater security of cloud computing, far better than any locally implemented solution (since the latter require considerable outlay and design expertise);

- Many countries enforce security measures on SaaS service providers, requiring them to restrict transmission of data and other copyright content to the contractor's country of origin ([13], p. 104)

As aptly put by J. Viega, one of the fundamental benefits of a cloud solution is the fact that those structures are fairly unrewarding for willful intruders, since the code - i.e. the most vulnerable element that can be tested for security holes and exploited - is stored on server side, instead of being sent to the client browser ([12], p.230). Data centralization in cloud structures, as opposed to decentralized distribution of data within the company network, allows for vast reduction of leak risk, since users are less inclined to store sensitive resources on their real machines. Furthermore, the access to a centralized resource storage and actual data use can be monitored more closely.

The concern for security of information exchanged in the course of company relations with external service providers, although well-founded, must be examined against any potential benefits offered by this particular type of business model. And the actual informational risk may be largely minimized by employing proper principles of management with respect to relations with external providers - this applies also to knowledge management. 


\section{Ways to reduce the risk of knowledge/information loss in IT sourcing models}

K. Liderman believes that information security can be enhanced by employing proper documentation of the security system in use. This task serves the following purposes [4, p.120]:

- to ensure proper level of protection with respect to information and to those elements of the system which are directly involved in data processing and storing;

- to track (and control) any changes introduced to the system;

- to satisfy the legal requirements that oblige companies to keep and produce on demand certain documents, such as 'security policy guidelines', 'safety instructions and procedures', etc. (the wording used in actual legal standards may vary).

The use of formal documents (information security policies or guidelines) may attest to the company's intent on keeping proper security standards in data protection. It may also help the organization build and maintain trust relations with customers and/or business partners. Lastly, it may also be used to stimulate the involvement of employees in all tasks and procedures related to data/information security.

With respect to basic technical security measures employed for the purpose of maintaining the informational stability of IT and telecommunication systems, Liderman provides the following classification of elements [4, pp. 158159]:

- data backup procedures;

- provision of independent backup power solutions;

- provision of backup solutions for data processing (or even for running the company business, if necessary), in a reasonably remote location from company HQs;

- doubling the key infrastructure: servers, routers, etc., to serve as backup;

- doubling the information packets;

- providing alternative transmission routes (doubling keys and operators);

- use of verified software offering suitable protection of transmitted and stored data (proper data transmission protocols, software-assisted verification of data integrity based on cryptographic methods, etc.);

- protecting the telecommunication and IT systems from unauthorized access - both physical (access to hardware and technical infrastructure) and logical (access to information resources); 
- protection from intentional or accidental exposure to hazards (fire, flooding, strong electromagnetic impulses, etc.).

The most advanced security measures used in cloud computing data centers include (own research, based on [13, pp. 104-114]):

- physical security - modern centers are often located in unassuming locations and buildings (often in residential areas), with good security and skillful use of barriers (also natural). Security services cover both the immediate area and the access to actual data facilities, using modern CCTV solutions, intruder alert systems, etc. Servers are kept in fortified bunkers, protected by 5-level biometric scanners (hand geometry recognition), round-the-clock patrols and traps (caging intruders in case of unauthorized entry). Physical security is solely in the hands of the cloud computing service provider, and the above measures are required for certification purposes (the SAS 70 Statement on Auditing Standards No. 70).

- access control in public clouds - these apply to verification of users accessing the cloud. The initial registration of a user is a multi-layered procedure, consisting of several overlapping secret questions and answers (e.g. the user's credit card details). Other levels of security verification may include invoice address, call-back verification over the phone (the out of band mechanism, based on employing a different channel of communication), login and authorization (the password should be strong), access keys (a good practice here is to provide regular key substitution service), X.509 certificates, paired keys (the latter being the most important element of user verification when working in cloud environment instances)

- network security and protection of data in large clouds. Passing the task on to the experts employed by the cloud service provider seems the best approach, since it may be reasonably assumed that the provider will be faster to respond to a potential intrusion attempt, and that the response will be adequate to the risk at hand. System security in public cloud models is verified at many levels: at the level of the host's operating system, at the level of the virtual machine's operating environment or the host system, at the stateful firewall, and at the level of signed API calls (the cloud application programming interface), with each subsequent level supplementing the capacities of its immediate precursor.

- The role and the responsibilities of the application owner. Cloud users themselves are responsible for security at the level of their host machine accessing the virtual instance. Since the users have full admin control over their accounts, services, and applications, they are responsible for 
basic security measures, such as the use of strong passwords, safe storage of passwords and private keys, as well as regular key substitution. Data stored in clouds should also be sufficiently protected - for example, by encrypting the resources prior to uploading them to the cloud, to make sure they cannot be read or modified during transmission and storage.

Modern organizations - both the IT customers and IT service providers should strive to identify and recognize all processes, services and resources considered mission-critical or of key importance from the information security viewpoint. They should also perform a reliable analysis of information risks, and take suitable measures and procedures to minimize the risk over the course of the cooperation with external partners. Thus, irrespective of the security solutions on offer by the service provider, they should employ their own, independent backup procedures with respect to sensitive data - such backup may be of great value if the company decides to withdraw from the contract (in such cases, the provider may refuse access to data stored in their system) or if the provider goes bankrupt.

Companies unwilling to put their trust in external providers, despite numerous obvious benefits offered by cloud computing solutions, can always reach for other models, such as those based on insourcing or the private cloud model.

The insourcing solution is based on internal management of IT services. If need arises, the company may purchase the lacking skills on the market for a limited time, for example by contracting additional personnel for the task. In this model, the organization retains its internal IT personnel and infrastructure, trusting in its ability to free the latent potential of its employees for the purpose of improving its IT services and making them more effective. From the viewpoint of the insourcing model, the internal IT department is formally perceived as a provider of services.

In the case of private cloud solutions, the decision to adopt this particular business model is made on the basis of four fundamental factors: security, accessibility, the size of user population, and the effect of scale (Table 1).

Table 1. Premises for adopting a private cloud solution

\begin{tabular}{|l|l|}
\hline \multicolumn{1}{|c|}{ Factor } & \multicolumn{1}{c|}{ Description } \\
\hline Security & $\begin{array}{l}\text { Applications require direct control and data protection, for confidentiality and } \\
\text { safety reasons (for instance, governmental agencies use dedicated applications } \\
\text { for processing of confidential and classified data - it is essential that they be } \\
\text { kept from unauthorized access). }\end{array}$ \\
\hline
\end{tabular}




\begin{tabular}{|l|l|}
\hline Accessibility & $\begin{array}{l}\text { Applications require access to a predefined set of processing resources, and } \\
\text { this type of access cannot be securely provided in a shared environment. }\end{array}$ \\
\hline $\begin{array}{l}\text { User popula- } \\
\text { tion }\end{array}$ & $\begin{array}{l}\text { The organization caters for many users, often in geographically remote loca- } \\
\text { tions, and they all require unrestricted access to computational processing re- } \\
\text { sources (private clouds are used, for example, in large telecommunication cor- } \\
\text { poration). }\end{array}$ \\
\hline $\begin{array}{l}\text { The effects } \\
\text { of scale }\end{array}$ & $\begin{array}{l}\text { Data centers and infrastructural resources are readily available, or can be ex- } \\
\text { panded at minimum cost. }\end{array}$ \\
\hline
\end{tabular}

Source: own research based on ([13], P.116).

Private clouds offer better control and assurance that the resources will not be used by other customers, since they are not shared in public space. However, as any other solution, the private cloud model has its own limitations, such as (own research, based on [13, pp.119-120]):

- limited scale of operation, compared to public clouds,

- the problem of adopting old applications to the cloud structure requirements without redesigning the very architecture of the system,

- limited potential for optimization and innovation of the methods and elements of the system,

- larger operational outlay compared to the public cloud solutions.

Even if the organization does not anticipate any integration with external providers when choosing their outsourcing solution, it may be advisable to keep an open stance in this respect, so that it may smoothly transition to another model if need arises, and not be too restricted with their choice of a potential provider.

\section{Conclusions}

New technologies, and the resulting new models and instruments for business, generate new and previously unforeseen risks and threats. Changes in company operating environment, brought about by globalization, increased competition, automation and - most of all - computerization, informatization and virtualization - require a new approach to knowledge management and information security in modern organizations.

The paper emphasizes the role of knowledge management in IT outsourcing projects. The analysis of organizational resources of contracting partners, informational needs and processes of information and knowledge management illustrates the vast number of factors that should be taken into account to mi- 
nimize the risk of improper 'utilization' of knowledge by any of the contracting parties and to provide effective cooperation between partners of the IT outsourcing project.

The most important conclusions that can be drawn from the above considerations include the following (based on [16]):

1) Organizations deciding on outsourcing its IT area should emphasize proper preparation steps, such as detailed analysis of needs and potential benefits as well as potential risks that may result from this type of organizational change.

2) Modeling of knowledge management processes in outsourcing relations and formulation of process maps (both for IT processes and information/communication processes) may effectively:

- limit the extent of communication problems with external provider,

- facilitate and streamline the implementation of IT outsourcing,

- improve security of organizational knowledge (through proper recognition and protection of core 'knowledge carriers', protected access to 'results' of the service provision after contract termination, etc.),

- improve information exchange between the organization and the service provider,

- improve information security (especially in cloud computing model),

- facilitate development of organizational knowledge in the course of the outsourcing contract, both in its organizational (project management knowledge) and technological aspect (of particular importance if the organization plans to restore in-house servicing of the outsourced tasks after contract termination),

- improve the outsourcing process in relation to the overall strategic objectives of the organization.

3) Building the atmosphere of trust and developing conditions for sharing knowledge between the contracting partners boosts the potential for developing sealed knowledge and innovation in cooperation with external companies.

4) Knowledge management in organizational relations with the IT service providers should be regarded as a module of a wider, comprehensive model of knowledge management formulated with the main purpose of identifying methods, instruments and relations for organizational survival and development, while at the same time limiting its dependence on external parties. 
As discussed in this paper, new IT sourcing models, especially cloud computing, offer some opportunities, but even if organizations themselves feel "cloud ready," they must anticipate the capacity requirements in the cloud. They must also be aware of new risks, and manage their IT security in accordance with the new operating conditions. The most important risk areas with respect to modern IT sourcing solutions (similarly to those observed in classical outsourcing models) include: the loss of control over the IT environment, inadequate protection of data, overdependence on external suppliers, the loss of potential to switch back to previous (self-contained) IT services, etc. A decision to adopt a particular IT sourcing solution should be based on such factors as: the size of the organization, the scale of operation, risk propensity, knowledge management model, the adopted information security policy, the personnel strategy, and the budget.

It seems that migration to a cloud model is a good solution for companies intent on maximizing their profits (cloud computing services are decidedly more cost-effective) while at the same time retaining their high standards of security. What makes the cloud computing particularly attractive for business entities is the fact that they can pass most of the IT system security responsibilities on to the service provider. The providers of cloud computing services, being well aware of the fact that security concerns are the most important factor to restrain companies from choosing the cloud model, make huge investments in security solutions and infrastructure, as a way to emphasize their responsible approach to the security of their clients' resources. Companies which - for a number of reasons - are unable or unwilling to rely on external partners with their data and knowledge, can reach for other sourcing models, such as the private cloud model or the insourcing model, to improve their IT effectiveness and both protect and develop internal knowledge in the IT area .

\section{References:}

[1] Oshri, I., Kotlarski, J., Willcocks, L.P.: The handbook of global outsourcing and offshoring. Second edition, Palgrave Macmillan Ltd. - Houndmills Basingstoke Hampshire (UK) (2011)

[2] Morgan, J.L., Bravard, R.: Inteligentny outsourcing. Sztuka skutecznej współpracy (in Polish), MT Biznes Sp. z o.o., Polska (2010)

[3] Szpor, G., Wiewiórowski, W. R. (eds.):, Wydawnictwo C.H. Beck, Warszawa (2012) 
[4] Liderman, K.: Bezpieczeństwo informacyjne (in Polish), Wydawnictwo Naukowe PWN, Warszawa (2012)

[5] Rot, A., Sobińska, M.: IT Security Threats in Cloud Computing Sourcing Model, Proceedings of the Federal Conference on Computer Science and Information Systems (2013 Federated Conference on Computer Science and Information Systems (FedCSIS),), pp. 1299 - 1303 (2013)

[6] Sobińska, M.: IT management business model - sourcing IT services. In: K. Perechuda (ed.): Advanced Business Models - in publishing (2014)

[7] Sparrow, E.: Successful IT Outourcing. Springer, London (2003)

[8] Strategies To Improve IT Efficiency In 2010.Using Predictive Analysis To Do More with Less, April 13, 2010, A Forrester Consulting Thought Leadership Paper Commissioned By TeamQuest, http://www.teamquest.com/pdfs/whitepaper/forrester-it-efficiency-2010.pdfaccessed on 18.04.2013 (2010) .

[9] Szpringer, W.: Wpływ wirtualizacji przedsiębiorstw na modele e-biznesu. Ujęcie instytucjonalne (in Polish), Oficyna Wydawnicza Szkoły Głównej Handlowej w Warszawie, Warszawa (2008)

[10] Willcocks, L.P., Lacity, M.C.: The new IT outsourcing landscape. From innovation to cloud services, Palgrave Macmillan Ltd. - Houndmills Basingstoke Hampshire (UK) (2012)

[11] Firmy lekceważą cyfrowe ataki (in Polish), Puls Biznesu, 27 Nov. 2013 (2013)

[12] Viega J.:Mity bezpieczeństwa IT. Czy na pewno nie masz się czego bać?(in Polish), Helion (2010)

[13] Mateos , A., Rosenberg, J.: Chmura obliczeniowa. Rozwiązania dla biznesu (in Polish), Helion, Gliwice (2011)

[14] Perechuda K., Sobińska M.: Information security in IT global sourcing models, Proceedings of the Federated Conference on Computer Science and Information Systems (FedCSIS 2014), https://fedcsis.org/proceedings/2014/, pp. 14411447 (2014)

[15] Willcocks L. P., Sobińska M.: IT Sourcing Management in Poland - Trends and Performance, the paper on The 9th Global Sourcing Workshop (February 18-21, 2015 La Thuile, Italy)- in review (2015)

[16] Sobińska M.: Modeling of knowledge management processes in IT outsourcing projects, Informatyka Ekonomiczna. Business Informatics 20/ 2011, ISSN 1507-3858, red. A. Bąk, A. Rot Wydawnictwo UE we Wrocławiu, Wrocław (2011)

[17] Ciesielska D.: Offshoring usług. Wpływ na rozwój przedsiębiorstwa (in Polish), Wolters Kluwer Polska, Warszawa (2009)

[18] Willcocks L.P., Lacity M.C.: The Practice of Outsourcing. From Information systems to BPO and Offshoring, Palgrave Macmillan Ltd. - Houndmills Basingstoke Hampshire (UK) (2009)

[19] Perechuda K., Sobińska M.: Zarządzanie informacją i wiedzą w outsourcingu IT (in Polish). In: J. Korczak, I. Chomiak-Orsa, H. Sroka (ed.).: Systemy in- 
formacyjne w zarządzaniu przedsiębiorstwem (in Polish) Wydawnictwo Uniwersytetu Ekonomicznego we Wrocławiu, Wrocław (2010) 